\title{
Miranda
}

Revue pluridisciplinaire du monde anglophone /

Multidisciplinary peer-reviewed journal on the English-

speaking world

19 | 2019

Rethinking Laughter in Contemporary Anglophone Theatre

\section{Willkommen, Bienvenue, Welcome: The Emcee and the Master of Metaphors in Bob Fosse's Cabaret}

Essay

\section{Gerrard Carter}

\section{(2) OpenEdition}

\section{Journals}

Electronic version

URL: http://journals.openedition.org/miranda/21233

DOI: $10.4000 /$ miranda.21233

ISSN: 2108-6559

\section{Publisher}

Université Toulouse - Jean Jaurès

\section{Printed version}

Date of publication: 7 October 2019

\section{Electronic reference}

Gerrard Carter, "Willkommen, Bienvenue, Welcome: The Emcee and the Master of Metaphors in Bob Fosse's Cabaret", Miranda [Online], 19 | 2019, Online since 11 October 2019, connection on 16 February 2021. URL: http://journals.openedition.org/miranda/21233 ; DOl: https://doi.org/10.4000/miranda. 21233

This text was automatically generated on 16 February 2021.

\section{c) $\$ \odot \Theta$}

Miranda is licensed under a Creative Commons Attribution-NonCommercial-NoDerivatives 4.0 International License. 


\section{Willkommen, Bienvenue, Welcome: The Emcee and the Master of Metaphors in Bob Fosse's Cabaret}

Essay

\section{Gerrard Carter}

\section{Excerpt}

1 https://www.youtube.com/watch?v=hBlB8RAJEEc\&t=6s

\section{Essay}

There was a dwarf MC, hair parted in the middle, and lacquered down with brilliantine, his mouth made into a bright-red cupid's bow, who wore heavy false eyelashes and sang, danced, goosed, tickled, and pawed four lumpen Valkyries waving diaphanous butterfly wings ${ }^{1}$. Hal Prince

Director-Producer Hal Prince describes a compelling visual that he encountered when visiting a nightclub near Stuttgart in 1951. This androgynous emblem of decadence served as inspiration for the Master of Ceremonies or MC (Emcee), a character that Prince created to serve as a magnetic force able to engage his audience to enter the glitter and impending doom of Weimar Berlin's transgressed underworld at the dawn of Nazi Germany.

3 First produced on Broadway in 1966, the musical Cabaret was destined to embark on a journey that sustained a number of stage incarnations over the next five decades both on Broadway and on London's West End including a slew of international productions around the world. Directed by Hal Prince with music and lyrics by renowned American 
songwriting team, composer John Kander and lyricist Fred Ebb, Cabaret was based on John Van Druten's 1951 play I am a Camera which was adapted from Christopher Isherwood's semiautobiographical novel Goodbye to Berlin (1939). When Prince successfully gained control of the rights to Van Druten's play, he enlisted the talents of writer Joe Masteroff to fashion his own version and provide the musical's book. Cabaret was a massive hit winning both the Tony Award and New York Drama Critics' Circle Award for Best Musical and played a total of 1,165 performances.

Prince recalls how the musical was named:

Calling it Cabaret was Joe Masteroff's idea. The life of the cabaret as a metaphor for Germany. In the first draft he and Kander and Ebb experimented with two scores running concurrently, one within the book for the personae, the other, pastiche for the entertainers (Prince 126).

5 To facilitate the notion that the cabaret was indeed a metaphor for Germany, the Kit Kat Klub was created to provide a fictional burlesque theater as a forum to showcase a distinct narrative of Berlin hedonism, sexual expression and confronting social commentary. Presiding over this cabaret of sublime decadence is the Emcee, an omnipresent force that encapsulates the many and varied facets of human nature.

When Cabaret opened on Broadway at the Broadhurst Theatre on November 20, 1966, Walter Kerr writing for the New York Times described the production as having elected to wrap its arms around all that was troubling and all that was intolerable with a demonic grin, an insidious slink, and the painted-on charm that keeps revelers up until midnight making false faces at the hangman.

7 Nobody quite captures the "demonic grin" and "painted-on charm" of which Kerr speaks quite like American actor Joel Grey who originated the role of the Emcee winning the Tony Award for Best Performance by a Featured Actor in a Musical. Kerr describing him as

cheerful, charming, soulless and conspiratorially wicked. In a pink vest, with sunburst eyes gleaming out of a cold-cream face, he is the silencer of bad dreams, the gleeful puppet of pretended joy, sin on a string.

Despite Grey's Broadway success, it was the 1972 film adaptation of Cabaret directed by Bob Fosse that Grey's performance garnered worldwide attention. Grey won both the Academy Award and Golden Globe for Best Supporting Actor, cementing his genius portrayal of the Emcee into the subconscious of contemporary culture.

Bob Fosse's background working in local nightclubs exposed him to the themes of vaudeville and burlesque performance. This unique way of life contributed greatly to the innovative thinking that leads to the film's decadent aesthetic. Fosse was committed to establishing an elevated level of authenticity in depicting the dark degeneracy of pre-war Berlin. Before filming, Fosse traveled to Germany to scout locations of underground clubs and bars for authenticity. He also searched for the weird and the wonderful, distinct faces that captured the Weimar era. Fosse expressed dissatisfaction with the commonplace Hollywood extra telling the Los Angeles Times that he was tired of "that same lollypop look over and over". He researched German artists that displayed the burnt out and disillusioned period of the 1920s in order to capture the Weimar demimonde of prostitutes, pimps, transvestites, sex and violence. Among the most intriguing artists was Otto Dix whose famous painting Portrait of the Journalist Sylvia von Harden (1926) is directly replicated in the opening minutes of the film. The subject's masculinized sharp-featured qualities with deep dull shadowed eyes 
sits smoking at a table starring impassively at the stage as she watches the Emcee and his varied assortment of performers.

The fact that Fosse chose to insert this painting into the opening sequence of the film as a frame within a frame and as a direct reference to the era, is quite compelling. When Otto Dix first approached his subject expressing his desire to paint her he exclaimed, "I must paint you! I simply must! You are representative of an entire epoch" ${ }^{2}$. Fosse understood what Dix was trying to say by comparing his subject to an entire epoch as he embraced the era with full force in his choice of the Kit Kat Klub dancers, a group of distorted ballerinas whose fixed gaze is devoid of all emotion. The sick pallor of their skin, their clown-like make-up and eyes perturbingly encircled in dark smoky rings exude a disturbing eroticism as they execute a series of signature Fosse slow-motion seductive moves. The motley crew of disproportionate bodies came in all shapes and sizes with Fosse going so far as to tell each woman to eat a big breakfast each morning before coming to work. He also insisted that the dancers stop shaving under their arms. As a result, the dancers looked spent, down and out, and disturbingly intriguing.

Fosse declared,

I tried to make the dancers look like the period, not as if they were done by me, Bob Fosse, but by some guy who is down and out. You think, 'Oh I can't really have them do that. That's so embarrassing; it's so bad, so cheap,' But you think, 'But if I were the kind of guy who works with cheap cabarets and clubs, what else would I do? So I worked from that, always trying to keep it lively, entertaining (Grubb, 149).

Keeping the Kit Kat Klub lively and entertaining is a cover for the slow rumble of the threatening storm that brews as the world awaits its full force with the death of sexual freedom and liberation. One such example is during a scene that features two overweight female mud-wrestlers. Moving through the audience is a young panhandler, a Sturmabteilung socialist brown-shirt who wears the all too familiar Nazi swastika insignia armband. Meaning Storm Detachment, the Sturmabteilung was the Nazi Party's original paramilitary who played a significant role in Adolf Hitler's rise to power in the 1920s and 1930s. Throughout the match the Emcee incites the crowd, hysterically laughing as he squirts water at the women. The crush of symbols can be heard as the harsh music accelerates the force of each blow. The crowd cheers and laughs loudly at the spectacle while the camera cuts to close-ups of various audience members hysterically laughing at the absurd situation. The young Sturmabteilung can be seen being quickly escorted from the club by its owner. During which time the Emcee suddenly jumps into the mud and triumphantly announces the winner of the match. $\mathrm{He}$ swipes a streak of mud across his upper lip to replicate Hitler's signature mustache and mimics a Nazi salute.

13 In the carnivalesque heightening the theatre of the absurd, the following example of Fosse following a socio-political narrative of this particular era can be seen during the comic variation on the traditional German folk dance the Schuhplattler. Schuhe meaning shoes, the performers stomp, clap and strike their thighs, knees and soles of their shoes with their hands flat (platt). The Emcee and accompanying Kit Kat Klub dancers are dressed in traditional lederhosen. This dance is contrasted with the same club owner who ejected the Sturmabteilung from the club, being beaten by Nazi youths. The violence is brutal and as the beating is juxtaposed by each comical slap, the scene takes on a sinister tone as it evolves into a motif that acts as a commentary to the disruptive political climate of the time. Bob Fosse's unique style in interspersing dramatic, and in this case, violent scenes throughout the theatrical performances staged at the Kit Kat 
Klub prompts the spectator to reflect on a painful past in world history when Germany was rife with anti-Semitism and the brutal violence that signified the degradation of humanity.

One musical number that was bold and extremely confronting in expressing the theme of anti-Semitism to contemporary audiences was the Emcee's last number that commented on the relationship between Fraulein Schneider and Herr Schultz. This is the moment when Fraulein Schneider breaks off the relationship because she fears the consequences of marrying a Jew. The Emcee's eerie yet comical and very entertaining soft-shoe number entitled "If You Could See Her through My Eyes" sings praises to his utter devotion towards a female gorilla. Dressed in top hat and suit, reminiscent of a carnival clown, the Emcee decorated with cheeks bright with red rouge, sings lovingly towards his girlish gorilla. The scene becomes mawkishly sentimental as the Emcee comically begs for understanding while mocking their ill-fated relationship. The scene is interspersed with the sound of laughter as the audience recognizes the impossibility of such a love. When he looks out towards the audience and sings "If you could see her through my eyes / She wouldn't look Jewish at all" the ramifications become all too apparent. The sound of laughter morphs into the insidious creep of fear of the Jews and the impending hatred that will in turn justify the atrocities committed towards a doomed population. The various acts performed throughout the night at the Kit Kat Klub become disturbing and act as an ominous prophecy of what was to come.

Throughout the 1972 film version of the Broadway musical, Bob Fosse was able to utilize the role of the Emcee to not only preside over the infamous Kit Kat Klub but to also serve as an indisputable force able to entail and depart a message of foreboding doom. Bob Fosse's Cabaret has already been recognized as an artistic triumph coupled with show-stopping numbers and a vehicle of star power. However, what is more striking is that Cabaret was a film courageous enough to embolden truth in order to provide a socio-political commentary that is still socially confronting in today's world.

\section{BIBLIOGRAPHY}

Grubb, Kevin Boyd. Razzle Dazzle: The Life and Work of Bob Fosse. New York: St. Martin's Press, 1989. Jennings, C. Robert. “Divine Decadence Provides the Theme for German 'Cabaret”, Los Angles Times, June 27, 1971.

Kerr, Walter. “The Theater: 'Cabaret' Opens at the Broadhurst”, New York Times, November 21, 1966.

Michalski, Sergiusz. New Objectivity: Painting, Graphic Art and Photography in Weimar Germany 1919-1933 Big Series Art. Köln: Taschen, 1994.

Prince, Hal. Contradictions: Notes on Twenty-Six Years in the Theatre. New York: Dodd, Mead, 1974. 


\section{NOTES}

1. See Prince $(1974,126)$.

2. See Michalski, $(1994,56)$.

\section{ABSTRACTS}

This essay examines the role of the Emcee in Bob Fosse's Cabaret and the film's capacity to provide a socio-political commentary that is still confronting today.

Cet essai examine le rôle de l'Emcee dans Cabaret de Bob Fosse et la capacité du film à fournir un commentaire socio-politique toujours confronté aujourd'hui.

\section{INDEX}

Keywords: Broadway, Bob Fosse, Cabaret, theatre, film, Decadence, Weimar Republic Mots-clés: Broadway, Bob Fosse, Cabaret, théâtre, film, décadence, République de Weimar Subjects: Theater

\section{AUTHORS}

\section{GERRARD CARTER}

$\mathrm{PhD}$

University of Melbourne, School of Languages and Linguistics

gerrardpcarter@gmail.com 